\title{
ARTHROSCOPIC TREATMENT FOR LATERAL EPICONDYLITIS: OUTCOMES IN 104 CASES OF A SINGLE INSTITUTION
}

\section{TRATAMENTO ARTROSCÓPICO PARA EPICONDILIOTE LATERAL: RESULTADOS EM 104 CASOS DE UMA ÚNICA INTITUIÇÃO} \author{
Olavo Pires de Camargo ${ }^{4}$ \\ 1. Hospital Orthoservice, Shoulder and Elbow Group, São José dos Campos, SP, Brazil. \\ 2. Escuela de Medicina, Colégio de Ciências de la Salud, Universidad San Francisco de Quito (USFQ), Quito, Ecuador. \\ 3. Hospital de los Valles, Orthopedics and Traumatology Department, Quito, Ecuador. \\ 4. Universidade de São Paulo, Faculdade de Medicina, Orthopedics and Traumatology Department, São Paulo, SP, Brazil.
}

alexandre Tadeu do Nascimento ${ }^{1}$, Gustavo Kogake Claudio ${ }^{1}$, Pedro Bellei Rocha ${ }^{1}$, Juan Pablo Zumárraga ${ }^{2,3}$,

\section{ABSTRACT}

Objective: To evaluate the outcomes of patients that underwent arthroscopic surgery for lateral epicondylitis (LE), after failed conservative treatment. Methods: One hundred four patients with LE treated with arthroscopic debridement of the extensor carpi radialis brevis (ECRB) tendon were enrolled in this retrospective study. They were evaluated using Disabilities of the Arm, Shoulder and Hand (DASH) score, Visual Analogue Scale (VAS) and Short Form Health Survey (SF-36) scale. Mean age at surgery was 46.9 years. Duration of symptoms was 2.1 years (range: $6 \mathrm{~m}$ to 10 yrs.). Mean follow-up was 34.4 months (range: 6 to $68 \mathrm{~m}$ ). Results: Mean postoperative scores were: 20.67 points on the DASH; 1.8 points on the VAS at rest, with 48 cases (46\%) without pain, $40(38 \%)$ with mild pain, $13(13 \%)$ with moderate pain and $4(4 \%)$ with severe pain; 4.7 points on the VAS in activity, with 21 (20\%) without pain, 21 (20\%) with mild pain, 35 (34\%) with moderate pain and 27 (26\%) with severe pain; and SF-36 was 66.8 points. Of the 23 patients who practiced sports regularly or with higher physical demand from the upper limbs, 17 (74\%) were able to return to the same activity at the same level. No significant complications were observed postoperatively, except for 3 (2.8\%) cases of postoperative superficial infection. Conclusion: Surgical treatment with arthroscopy for recalcitrant LE is effective and safe, presenting positive outcomes in the studied patients. Level of evidence IV, Case Series.

Keywords: Lateral Epicondylitis. Tennis Elbow. Elbow Joint. Arthroscopic Surgery. Tendon Injuries. Rehabilitation.

\section{RESUMO}

Objetivo: Avaliar os resultados dos pacientes submetidos a tratamento cirúrgico artroscópico da epicondilite lateral (EL) refratária depois da falha no tratamento conservador. Métodos: Estudo retrospectivo que incluiu 104 pacientes submetidos a desbridamento artroscópico do tendão extensor radial curto do carpo (ERCC) para tratamento de EL. Os pacientes foram avaliados pelo escore de DASH, pela classificação visual analógica de dor (EVA) e pelo Short-Form 36 (SF36). A média da idade foi de 46,9 anos (variação de 30 a 69 anos). O tempo de sintomas foi de 2,1 anos (variação de 6 meses a 10 anos). O seguimento médio foi de 34,4 meses (variação de 6 - 68 meses). Resultados: A média dos escores pós-operatórios foi de: 20,67 pontos no DASH; 1,8 pontos no EVA de repouso, sendo 48 (46\%) sem dor, 40 (38\%) com dor leve, 13 casos (13\%) com dor moderada e 4 (4\%) com dor intensa; 4,7 pontos no EVA em atividade, sendo 21 (20\%) sem dor, 21 (20\%) com dores leves, 35 (34\%) com dores moderadas e 27 (26\%) com dores intensas; e SF-36 de 66,8. Dos 23 pacientes em prática constante de esporte ou com maior demanda física nos membros superiores, 17 (74\%) conseguiram retornar ao mesmo nível. Não observamos complicações significativas exceto por 3 (2,8\%) casos de infecção pós-operatória superficial. Conclusão: O tratamento artroscópico para EL recalcitrante do cotovelo é eficaz e seguro, apresentando resultados positivos. Nível de Evidencia IV, Série de Casos.

Descritores: Epicondilite Lateral. Cotovelo de Tenista. Articulação do Cotovelo. Artroscopia. Traumatismos dos Tendões. Reabilitação.

Citation: Nascimento AT, Claudio GK, Rocha PB, Zumárraga JP, de Camargo OP. Arthroscopic treatment for lateral epicondylitis: outcomes in 104 cases of a single institution. Acta Ortop Bras. [online]. 2019;27(3):156-9. Available from URL: http://www.scielo.br/aob.

All authors declare no potential conflict of interest related to this article.

Study conducted at Hospital Orthoservice, São José dos Campos, SP, Brazil and at the Orthopedics and Traumatology Institute, Hospital das Clínicas HCFMUSP, Faculdade de Medicina, Universidade de São Paulo, São Paulo, SP, Brazil.

Correspondence: Juan Pablo Zumárraga. Rua Ovídio Pires de Campos, 333, Cerqueira Cesar, São Paulo, SP, Brazil. 05403-010. juanpzumarraga@ @hotmail. 


\section{INTRODUCTION}

Lateral epicondylitis (LE) is the most common elbow-related pain complaint, affecting up to $3 \%$ of the adult population annually. ${ }^{1}$ Despite the classical description of tennis elbow, only $10 \%$ of the patients that present LE are tennis players, being the majority of the cases related to occupational activities. ${ }^{2}$ Tendons are relatively hypovascular in the area close to the insertion. This hypovascularity predispose the tendons to hypoxic degeneration and has been implicated as a possible cause of LE. The most common primary pathology is tendinosis of the ECRB, 1-2 centimeters $(\mathrm{cm})$ from its fixation on the lateral epicondyle, with the development of the characteristic angiofibroblastic invasion. ${ }^{3}$ It is a self-limited pathology, with the majority of the patients improving with conservative treatment. However, some factors such as duration of the symptoms, prior infiltration, prior orthopedic surgery, and workers' compensation, are known factors of poor prognosis, increasing the probability of surgical intervention as treatment. ${ }^{4}$ Recurrence of LE has being described in $8.5 \%$ of the cases. Patients with over six months of pain, approximately $6 \%$ of all the cases ${ }^{5}$, have a greater chance of being symptomatic for longer periods, commonly requiring surgery as the definitive treatment. Surgical intervention can be very effective for recalcitrant cases of LE, with a large percentage of individuals reporting improvement. ${ }^{6}$ Several surgical procedures have been described for this condition. ${ }^{7-9}$ The majority of the techniques releases or debrides the ECRB tendon. Some factors, especially female patients and a common extensor tendon injury bigger than 6 milimeters $(\mathrm{mm})$, diagnosed by magnetic resonance, have been associated with poor prognosis after surgical intervention. ${ }^{10}$ Arthroscopic surgical treatment of lateral epicondylitis has advantages when compared with open surgery. The most important are: the ease for debriding the lower surface of the tendon without invading the common extensor aponeurosis (Figure 1), complete access to asses any intra-articular pathology and shorter rehabilitation time. ${ }^{11}$

\section{MATERIALS AND METHODS}

This is a retrospective study of 104 patients that underwent arthroscopic debridement of the ECRB to treat LE. Included patients had unsatisfactory or no improvement at all with the conservative treatment. Conservative treatment consisted of six months of physical therapy with the proper orthesis, two intramuscular infiltrations with corticosteroids and pain medications. Patients with chondral lesions, signs of arthrosis and previous elbow surgery were excluded from the study. The function of all the patients was evaluated using DASH, VAS and SF-36 scales in the pre-operative period and in the post-operative follow-up.

\section{Operative technique}

The operative technique used was based on published descriptions ${ }^{1,7}$ with certain adaptations. The patient was positioned in the opposite lateral decubitus of the injured elbow, under general anesthesia. A brachial plexus block was also performed. An elbow support was also used, to allowed a $90^{\circ}$ flexion and full extension of the elbow during the procedure. Also, a pneumatic tourniquet placed at the proximal region of the arm was used. Surgical landmarks of the olecranon, the epicondyles, the head of radius, and the ulnar nerve were drawn. The elbow articulation was inflated with 40 milliliters $(\mathrm{ml})$ of saline solution, through a puncture in the middle of the imaginary triangle formed by the lateral epicondyle, the head of radius, and the olecranon, to facilitate the entry of the arthroscope in the intra-articular space. We preferentially used the anterior superomedial and anterior superolateral portals, beginning with the former, through which the trocar and scope is placed. The second portal was made using a needle under intra-articular visualization to optimize its positioning. A complete analysis of the anterior compartment of the elbow joint was performed, including the articular and capsule surfaces. Then, a partial capsulotomy of the lateral region was performed to allow the visualization of the origin of ECRB tendon, which is extra-articular. With a radio frequency device, the ECRB tendon was removed from the humerus. Thereafter, the tendon was debrided with an arthroscopic shaver and the lateral region of the humerus with a bone shaver, with the intention to cause bleeding and cellular migration to the region. The ECRB was not reinserted. The collateral ligament can be damaged if the resection of the ECRB is performed without direct visualization, because of the collapse of the anterior soft tissues; therefore, we used an infusion pump to keep the joint inflated.

\section{Post-operative}

During the first five post-operative days, the patients used an arm sling for comfort and pain control. Movements were allowed depending on pain. No extraordinary efforts with the operated limb were allowed during this period. Frequently, the normal range of motion of the elbow was achieved after two weeks of physiotherapy. After achieving the normal range of motion, muscular isometric strengthening exercises for approximately four weeks were prescribed. Exercises with resistance were initiated six weeks after surgery and were indicated for six weeks. Unrestricted movements of the limb were allowed after this 12 weeks of therapy.

\section{RESULTS}

Of the 104 patients, 71 (69\%) were male and 33 (31\%) female. The mean age at surgery was 46.9 years (range from 30 to $69 \mathrm{yrs}$ ). The duration of the symptoms prior to surgery was approximately 2.1 years (range from $6 \mathrm{~m}$ to $10 \mathrm{yrs}$ ). The mean follow-up time was 34.4 months (range from 6 to $68 \mathrm{~m}$ ). A total of 72 right and 32 left elbows were operated. The dominant arm was affected in $67 \%$ of the cases. The mean postoperative scores were: 20.67 points on DASH; 1.8 points on the VAS at rest, 48 (46\%) without pain, 40 (38\%) with mild pain, 13 (13\%) with moderate pain, and 4 (4\%) with severe pain; and 4.7 points on the VAS in activity, 21 (20\%) without pain, 21
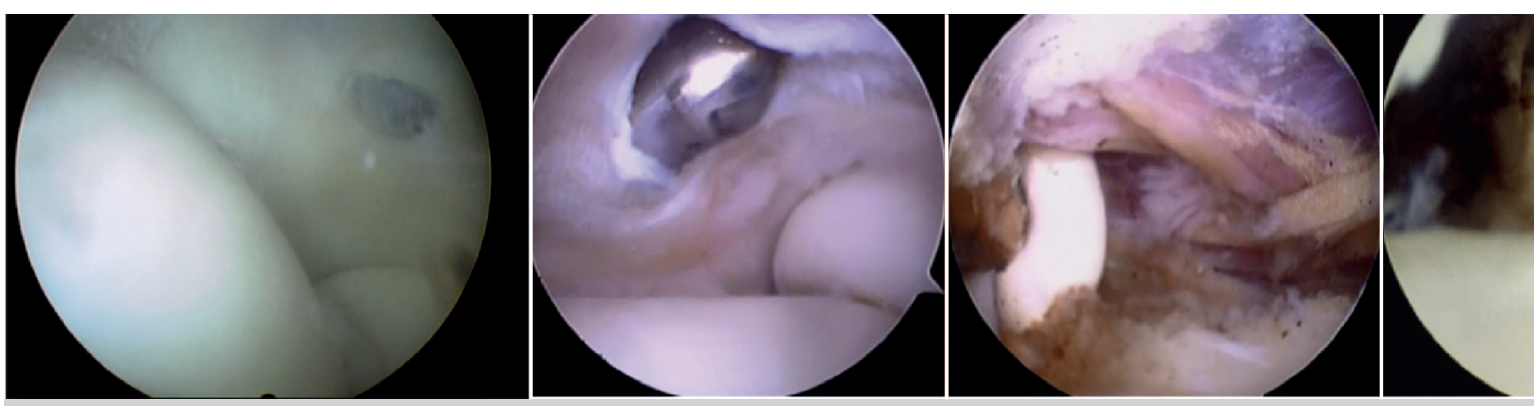

Figure 1. Results of DASH and VAS scores. 
(20\%) with mild pain, 35 (34\%) moderate pain, and 27 (26\%) with intense pain (Table 1). The mean SF-36 score was 66.8 (Table 2). Of the 23 patients with demanding physical activities including sports, 17 (74\%) were able to return to the same activity at the same level. Sixteen patients were receiving welfare benefits and when we analyzed their results using VAS score, we noticed that this tend to worsen their results when compared to patients without benefits, but this difference was not statistically significant (Table 3). Five patients did not present any improvement in the scores evaluated. We did not observe any significant complications with the arthroscopic procedure, except for $3(2.8 \%)$ cases of superficial postoperative infection. The results of the SF-36 are subdivided and detailed in Table 2. The statistical analysis was performed by comparing the pre and post-operative measures with the Student $t$-test. Two-tailed and paired tests were used in all cases, and those having $p$ values $<0.01$ were considered statistically significant. The statistical program SPSS was used in the analysis.

\section{DISCUSSION}

$\mathrm{LE}$ is the most common elbow-related pain complaint in adults. Also, it frequently responds well to conservative treatment. Surgical intervention is required, eventually, when symptoms are unsatisfactory or do not improve at all, after at least six months of physiotherapy; this occurs in approximately $16 \%$ of the cases. ${ }^{5} \mathrm{~A}$ similar rate was observed in our study. We evaluated the functional response and pain in this group of patients with refractory conservative treated epicondylitis, who submitted to arthroscopic debridement of the ECRB tendon. A significant improvement was observed in almost all the evaluated scores. The results obtained with VAS scores are in agreement with the literature, with a slight improvement when measured in the patients at rest..$^{12}$ In a publication that compares arthroscopic versus percutaneous techniques for the treatment of LE, DASH score was assessed preoperatively and postoperatively, showing significant improvement in the results $(p<0.05)$. It went from 72 to 48 points in the arthroscopic cases and from 70 to 50 points in the percutaneous cases. ${ }^{13}$ Patients in this study, had a

Table 1. Results of DASH and VAS scores.

\begin{tabular}{c|c|c}
\hline & DASH & VAS \\
\hline Pre-operative & $48.9 \pm 21(3.33-90)^{\star}$ & $7.6 \pm 1.9(1-10)^{\star}$ \\
\hline Post-operative at rest & $21.24 \pm 20.6(0-63.3)^{\star}$ & $1.8 \pm 2.2(0-3)^{\star}$ \\
\hline Postoperative in activity & -- & $4.8 \pm 3.3(0-10)^{\star}$ \\
\hline p value & $<0.001$ & $<0.001$ \\
\hline
\end{tabular}

*Mean and the standard deviation, with the range between parentheses.
Table 3. Results of the VAS comparing patients with and without welfare aid.

\begin{tabular}{c|c|c}
\hline & Pain at rest & Pain in activity \\
\hline Patients without welfare benefits & $1.5+2.7(0-8)^{*}$ & $4.3+3.4(0-10)^{*}$ \\
\hline Patients with welfare benefits & $2.7+2.8(0-8)^{*}$ & $5.7+2.9(2-9)^{*}$ \\
\hline p value & 0.17 & 0.22 \\
\hline
\end{tabular}

* Mean and standard deviation values, with the range between parentheses.

DASH mean score of 21.2 points, showing a better outcome when compared with literature. Nonetheless, our preoperative DASH mean score was also better if compared with other publications. Emphasis has been placed on the psychological aspects that are associated with patients who develop recalcitrant LE. ${ }^{14}$ Although we did not measure these aspects directly through specific questionnaires, we noticed by the SF-36 analysis, that there was a statistically significant improvement in these parameters, which mean that even psychological factors can be improved after appropriate treatments. Some studies suggest that, regardless of the technique, the results of surgery for LE are not uniform. Verhaar et al. ${ }^{15}$ reported a $66 \%$ rate of satisfaction at 1 year follow-up, with $30 \%$ of the patients returning to their daily activities. In our study, $46 \%$ of the patients remained without pain after 1 year follow-up, but only $20 \%$ returned to their activities. An advantage of the arthroscopic treatment for LE is the possibility of early rehabilitation. Owens et al. ${ }^{9}$ reported 16 patients who improved after arthroscopic release, with a mean return to work with no restrictions of six days after surgery. In our study, despite immediate movement after the procedure, patients only returned to their normal activities after 12 weeks of the surgery. Baker et al. ${ }^{16}$ published the results of a long-term cohort study, reporting that patients who were well after 2 years follow-up, maintained their level of function, without worsening of pain. Despite the good results demonstrated in publications, we must note that approximately $26 \%$ of the patients who practiced sports, with emphasis in the upper limbs, were not able to return to the level at which they were practicing. In some cases the result was a change of the sport practiced. Also, $5 \%$ of the patients in our study didn't achieve any improvement with the surgical treatment. We also observed, as other publications, ${ }^{17}$ that patients who have welfare benefits tend to worsen their outcomes. Nevertheless, we believe that there is benefit with the surgical treatment in patients with chronic symptoms, although studies show similar results between surgical approach and placebo. ${ }^{18}$

\section{CONCLUSION}

Surgical treatment through arthroscopy for recalcitrant LE is effective and safe, presenting positive outcomes in the studied patients.

Table 2. Comparative pre and postoperative results of the SF-36.

\begin{tabular}{|c|c|c|c|c|c|c|c|c|}
\hline & $\begin{array}{c}\text { Functional } \\
\text { capacity }\end{array}$ & $\begin{array}{c}\text { Limitation by } \\
\text { physical aspects }\end{array}$ & Pain & $\begin{array}{l}\text { Overall health } \\
\text { status }\end{array}$ & Vitality & Social aspects & $\begin{array}{l}\text { Limitations by } \\
\text { emotional aspects }\end{array}$ & Mental health \\
\hline Pre-op & $\begin{array}{c}63.7 \pm 25.1 \\
(15-100)^{*} \\
\end{array}$ & $\begin{array}{c}20.1 \pm 33.8 \\
(0-100)^{*} \\
\end{array}$ & $\begin{array}{c}32.9 \pm 17.1 \\
(0-80)^{*}\end{array}$ & $\begin{array}{l}62 \pm 19.6 \\
(10-100)^{*} \\
\end{array}$ & $\begin{array}{c}65 \pm 26.2 \\
(1-100)^{*}\end{array}$ & $\begin{array}{c}69.4 \pm 24.6 \\
(0-100)^{*}\end{array}$ & $\begin{array}{c}32.9 \pm 43.6 \\
(0-100)^{*} \\
\end{array}$ & $\begin{array}{c}70 \pm 21.7 \\
(8-100)^{*}\end{array}$ \\
\hline Post-op & $\begin{array}{c}76.4 \pm 21.5 \\
(5-100)^{*}\end{array}$ & $\begin{array}{c}48.1 \pm 48 \\
(0-100)^{*}\end{array}$ & $\begin{array}{c}61.1 \pm 25.8 \\
(0-100)^{*}\end{array}$ & $\begin{array}{c}57.7 \pm 14.5 \\
(5-85)^{*}\end{array}$ & $\begin{array}{c}82.3 \pm 17.1 \\
(40-100)^{*}\end{array}$ & $\begin{array}{l}64.3 \pm 14.6 \\
(37.5-100)^{*}\end{array}$ & $\begin{array}{c}62.8 \pm 47 \\
(0-100)^{*}\end{array}$ & $\begin{array}{l}83 \pm 14.5 \\
(48-100)^{*}\end{array}$ \\
\hline$p$ value & $<0.01$ & $<0.01$ & $<0.01$ & 0.25 & $<0.01$ & 0.18 & $<0.01$ & $<0.01$ \\
\hline
\end{tabular}

*Mean and the standard deviation, with the range between parentheses.

AUTHORS' CONTRIBUTIONS: Each author made significant individual contributions to this manuscript. ATN (0000-0003-3044-959X)*, GKC (0000-00029830-754X)*, PBR (0000-0001-5089-1022)*, JPZ (0000-0001-5941-7714)*, OPC (0000-0002-1128-7292)*, were the main contributors in writing this work. ATN participated in: research, design, writing and data collection; GKC participated in: concept, research, writing and data collection; PBR participated in: concept, research, writing and data collection; JPZ participated in: writing, concept, design, and analysis; OPC participated in: concept, writing and analysis. *ORCID (Open Researcher and Contributor ID). 


\section{REFERENCES}

1. Lattermann C, Romeo AA, Anbari A, Meininger AK, McCarty LP, Cole BJ. Arthroscopic debridement of the extensor carpi radialis brevis for recalcitrant lateral epicondylitis. J Shoulder Elbow Surg. 2010;19(5):651-6.

2. Boyer MI, Hastings $\mathrm{H}$ 2nd. Lateral tennis elbow: "is there any science out there? J Shoulder Elbow Surg. 1999;8(5):481-91

3. Altan L, Kanat E. Conservative treatment of lateral epicondylitis: comparison of two different orthotic devices. Clin Rheumatol. 2008;27(8):1015-9.

4. Knutsen EJ, Calfee RP, Chen RE, Goldfarb CA, Park KW, Osei DA. Factors associated with failure of nonoperative treatment in lateral epicondylitis. Am J Sports Med. 2015;43(9):2133-7.

5. Baker CL Jr, Murphy KP, Gottlob CA, Curd DT. Arthroscopic classification and treatment of lateral epicondylitis: two-year clinical results. J Shoulder Elbow Surg. 2000;9(6):475-82.

6. do Nascimento AT, Claudio GK. Arthroscopic surgical treatment of recalcitrant lateral epicondylitis - a series of 47 cases. Rev Bras Ortop. 2017;52(1):46-51.

7. Baker CL. Arthroscopic versus open techniques for extensor tenodesis of the elbow. Tech Shoulder Elbow Surg. 2000;1:184-91.

8. Baumgard SH, Schwartz DR. Percutaneous release of the epicondylar muscles for humeral epicondylitis. Am J Sports Med. 1982;10(4):233-6.

9. Owens BD, Murphy KP, Kuklo TR. Arthroscopic release for lateral epicondylitis. Arthroscopy. 2001;17(6):582-7.

10. Yoon JP, Chung SW, Yi JH, Lee BJ, Jeon IH, Jeong WJ. Prognostic factors of arthroscopic extensor carpi radialis brevis release for lateral epicondylitis.
Arthroscopy. 2015;31(7):1232-7.

11. Szabo SJ, Savoie FH, Field LD, Ramsey R, Hosemann CD. Tendinosis of the extensor carpi radialis brevis: an evaluation of three methods of operative treatment. J Shoulder Elbow Surg 2006;15(6):721-7.

12. Oki G, Iba K, Sasaki K, Yamashita T, Wada T. Time to functional recovery after arthroscopic surgery for tennis elbow. J Shoulder Elbow Surg. 2014;23(10):1527-31.

13. Othman AM. Arthroscopic versus percutaneous release of common extensor origin for treatment of chronic tennis elbow. Arch Orthop Trauma Surg. 2011;131(3):383-8

14. Aben A, De Wilde L, Hollevoet N, Henriquez C, Vandeweerdt M, Ponnet K, et al. Tennis elbow: associated psychological factors. J Shoulder Elbow Surg. 2018;27(3):387-92.

15. Verhaar J, Walenkamp $G$, Kester A, van Mameren $H$, van der Linden T. Lateral extensor release for tennis elbow: a prospective long-term follow-up study. J Bone Joint Surg Am. 1993;75(7):1034-43.

16. Baker CL Jr, Baker CL III. Long-term follow-up of arthroscopic treatment of lateral epicondylitis. Am J Sports Med. 2008;36(2):254-60.

17. Sanders TL, Kremers HM, Bryan AJ, Ransom JE, Smith J, Morrey BF. The epidemiology and health care burden of tennis elbow: a population-based study. Am J Sports Med. 2015;43(5):1066-71.

18. Kroslak M, Murrell GAC. Surgical treatment of lateral epicondylitis: a prospective, randomized, double blinded, placebo controlled clinical trial. J Shoulder Elbow Surg. 2017;26(10):e328-9. 